\title{
ARGUMENTS OF DIGNITY AND PLURALISM CONCERNS IN RECENT CONSTITUTIONAL COURT ADJUDICATION
}

\author{
ARGUMENTOS DE PREOCUPAÇÃO DE DIGNIDADE E PLURALISMO \\ NA ADJUDICAÇÃO RECENTE DO TRIBUNAL CONSTITUCIONAL
}

Angioletta Sperti (iD)

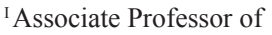
Comparative Public Law, University of Pisa, Piazza dei Cavalieri, 2 Pisa (Italy). E-mail: angioletta.sperti@unipi.it
}

\begin{abstract}
The paper aims at discussing the growing importance of dignity discourse in human rights case law, in particular in recent constitutional and supreme courts cases on controversial rights. Starting from same-sex marriage rulings (as illustrative of a more general trend) the paper argues that dignity cannot be considered a mere "rhetorical tool" of courts, useful to tilt the balance in favour of one of the conflicting rights. On the contrary, dignity - with its wide and flexible meaning - marks the transition of new (or newly recognized) groups to social inclusion and provides a convenient language to mediate among conflicting claims of recognition without relying on more traditional equality arguments.
\end{abstract}

Keywords: Dignity. Pluralism. Constitutional court.

Resumo: O artigo tem como objetivo discutir a crescente importância do discurso da dignidade na jurisprudência em direitos humanos, em particular em casos recentes de tribunais constitucionais e supremos sobre direitos controversos. A partir de decisões sobre casamento entre pessoas do mesmo sexo (como ilustração de uma tendência mais geral), $\mathrm{o}$ artigo argumenta que a dignidade não pode ser considerada uma mera "ferramenta retórica" dos tribunais, útil para inclinar a balança em favor de um dos direitos conflitantes. Pelo contrário, a dignidade - com seu significado amplo e flexível - marca a transição de novos (ou recém-reconhecidos) grupos para a inclusão social e fornece uma linguagem conveniente para mediar entre reivindicações conflitantes de reconhecimento sem depender de argumentos de igualdade mais tradicionais.

Palavras-chave: Dignidade. Pluralismo. Tribunal Constitucional. 


\section{Introduction}

In the last few years dignity discourse in constitutional adjudication and in public and political debates has significantly increased (McCrudden 2014, 1). The most recent constitutional courts' cases - especially on controversial human rights - reveal an increasing use of dignity arguments. This development has stimulated large attention by constitutional scholars who have defined the "success" of dignity as a "global phenomenon" (Barak, 2015).

In particular, protection of human dignity has been invoked in cases concerning abortion, reproductive rights, assisted suicide, genetic engineering and manipulation, freedom of expression, migration both in order to support and to oppose the recognition of those rights. For this reason, some scholars emphasise that dignity is "culturally dependent and flexible" (Feldman, 1999, 69) or "confusing" (O’Mahoney, 2012, 552 ) and that it can be used as a rhetorical tool or an "argumentative topos" (Vincenti, 2009, 105 ff.).

Arguments of dignity occur repeatedly not only in European constitutional courts' - due to the influence of German constitutional scholarship and legal cases - but also in other jurisdictions with different constitutional traditions. In the United States, for instance - where the federal Constitution does not even mention dignity due to its cultural and historical origins - references to dignity in constitutional cases were quite rare in the past and they occured mostly within dissenting opinions (Rao 2008, 202) and in connection with liberty and self-determination. In the most recent cases, the United States Supreme Court has instead referred to dignity in connection with equality and individual freedom. Tribe (2005) has described the narrow relationship of dignity with both liberty and equality with the metaphor of the "double helix" and has emphasized the implications of dignity discourse for future constitutional adjudication. Analogously, in Canada and India - where 
human dignity is not explicitly stated in the constitutional documents, dignity has been increasingly mentioned by courts (Daly, 2013).

Arguments of dignity have been especially important for the recognition of the rights of LGBTI people and of same-sex couples (Sperti, 2017, 154 ff.). In this field of the law, due its adaptability and flexibility, the principle of human dignity has been expounded in different constitutional contexts, therefore increasing the dialogue among constitutional and supreme courts on LGBT rights. At the same time, as sexual orientation equality issues have been addressed by most constitutional and supreme courts in the last twenty years, the cases offer the opportunity of a deep analysis of the circulation of legal arguments (Sperti 2017 and Zanetti, 2015).

Moving from the different meanings of dignity in same-sex marriage cases, in this paper I aim at demonstrating that dignity should not be considered a tool, useful for influencing the outcome of the cases and tilting the balance in favor of one of the conflicting constitutional rights at stake. I will clarify the different purposes that dignity serves in same-sex marriage cases, in order to demonstrate the reasons why constitutional and supreme courts often resort to dignity instead to traditional equality and liberty arguments.

2 Different meanings of dignity in same-sex marriage cases

It has been frequently pointed out that the concept of dignity is complex and multifaceted ${ }^{1}$ and that it is difficult to identify, beyond a basic common core, a universalistic understanding of dignity across different jurisdictions.

Although it is not easy to mark a clear distinction among the different meanings of dignity in same-sex marriage cases, it should be emphasized that, in the first place, the principle of dignity has been frequently referred to the sociality of same-sex couples and to their

1 See, See Case C-36/02 Omega Spielhallen und Automatenaufstellungs-GmbH v Oberbürgermeisterin der Bundeststadt Bonn [2004] ECR I-09609 ('there is hardly any legal principle more difficult to fathom in law than that of human dignity'). 
aspiration to social recognition and respect (Sperti, 2017, 156). In this perspective, dignity stems from the assumption of the equal worth of all individuals and it entails interpersonal respect, public recognition and mutual concern. Therefore, dignity is strictly related to equality and to the idea that the State must guarantee protection in order to preserve individual self-image and standing in the community (Hoffman, 1993, p. 352 ff.).

The Canadian courts have frequently emphasized this dimension of dignity and its relationship with equality of minorities and social groups. "Human dignity - the Supreme Court of Canada clarifiedmeans that an individual or group feels self-respect and self-worth. ... Human dignity is harmed when individuals and groups are marginalized, ignored, or devalued, and is enhanced when laws recognize the full place of all individuals and groups within Canadian society. Human dignity within the meaning of the equality guarantee does not relate to the status or position of an individual in society per se, but rather concerns the manner in which a person legitimately feels when confronted with a particular law ".

As I have argued in a previous work (Sperti, 2017, 142 ff.), in same-sex marriage cases dignity as recognition emerges in relation to the "expressive value" of marriage: proponents of equal marriage argue that same-sex couples should be allowed to marry (or to choose marriage as the form for their intimate relationship) on equal terms to differentsex couples because of the social and "expressive" (Nussbaum, 2010, 129) value attached (by couples themselves and by their community) to marriage. Marriage as a social institution has in fact "an iconic and ideological status" (Diduck- Canagas, 2012, 37), because the spouses' mutual public statement of love and commitment in front of witnesses, relatives and friends has not only a value for the couple itself - as it validates and reinforces their mutual and (potentially) life-enduring

2 Law v Canada [1999] 1 SCR 497, 170 DLR (4th) 1, § 53. 
bond - but also a social value, because it makes the union recognized and sanctioned in public.

The Ontario Court of Appeal emphasized in Halpern ${ }^{3}$ the importance of marriage for the expression of love and mutual commitment of same-sex couples. The Court interpreted dignity in relation to the self-fulfillment of the individual in the intimate sphere as well as a 'claim of recognition' on the public plane because marriage conveys a message of approbation by society.

In South Africa, the Constitutional court in Fourie referred same-sex marriage to the ideals of "a democratic, universalistic, caring and aspirationally egalitarian society". ${ }^{4}$ Writing for the majority of the Court, Justice Sachs argued that the formalities for marriage "make certain that it is known to the broader community precisely who gets married and when they get married" because the words "I do" bring the most intense private and voluntary commitment into the most public, law-governed and state-regulated domain'. ${ }^{5}$ Furthermore, he argued that section 9(1) and (3) of the Constitution - that include sexual orientation within the prohibited grounds of discrimination - protected "the right to be acknowledged as equals and to be embraced with dignity by the law. [Same- sex couples'] love that was once forced to be clandestine, may now dare openly to speak its name. The world in which they live and in which the Constitution functions, has evolved from repudiating expressions of their desire to accepting the reality of their presence, and the integrity, in its own terms, of their intimate life. Accordingly, taking account of the decisions of this Court, and bearing in mind the symbolic and practical impact that exclusion from marriage has on same-sex couples, there can only be one answer to the question as to

3 Halpern v Canada, (2003) OJ No 2268, 65 OR (3d) 161 (Can. Ont. C.A.).

4 Minister of Home Affairs and Another v Fourie, Case CCT 60/04, [2005] ZACC $19, \S 60$.

5 Ibidem, $\S \S 63-4$. 
whether or not such couples are denied equal protection and subjected to unfair discrimination."

In the second place, dignity comes into consideration in same-sex marriage cases as referred to the inherent worth of all human beings. In this meaning, dignity is not conceived as the result of the development of personality, but as an inherent quality of each individual by virtue of his humanity. As it has been emphasized, "inherent dignity focuses on human potential - not the exercise of such potential" (Rao, 2011, p. 187); it is related to formal equality but basically encompasses the liberal notion of negative freedom and the idea that the state should not restrain individual autonomy.

This universal and open sense of dignity (Rao, 2011) can be found in same-sex marriage cases where courts emphasise the importance of marriage in terms of "the transition of homosexuals from exclusions to inclusion into full citizenship" (Finck, 2016). In this perspective, recognition of the right for same-sex couples to marry assumes an idea of dignity as equal worth of all human beings and implies social acceptance. This also implies the unconstitutionality of the so called "double-track" regime, i.e. of the choice (adopted in the past by Germany or still in force in Italy) to reserve marriage to opposite-sex couples and civil unions to same-sex couples.

In the United States, state courts have often invoked human dignity, emphasising the "second-class citizen status" of gays and lesbians who have been denied the protection, benefits and obligations conferred to heterosexuals, including marriage, for a long time. As early as in 2003, in Goodridge v Department of Public Health, for instance, the Supreme Judicial Court of Massachusetts noted that "the Massachusetts Constitution affirms the dignity and equality of all individuals" and "it forbids the creation of second-class citizens". 7 The Supreme Court of California in In Re Marriage Cases, argued instead

6 Ibidem, $\S \S 78$.

7 Goodridge v Department of Public Health, 440 Mass 309 (2003), 312. 
that even "the failure to designate the official relationships of same-sex couples as marriage' amounts to a violation of dignity and equality of same-sex couples" ${ }^{8}$. Observing that under the current statutes, the state ha[d] not revised the name of the official family relationship for all couples, but rather ha[d] drawn a distinction between the name for the official family relationship of opposite-sex couples (marriage) and that for same-sex couples (domestic partnership), the California Supreme Court observed that "one of the core elements of the right to establish an officially recognized family that is embodied in the California constitutional right to marry is a couple's right to have their family relation- ship accorded dignity and respect equal to that accorded other officially recognized families". 9

Therefore, it concluded that the challenged legislation, assigning a different designation for the family relationship of same-sex couples while reserving the historic designation of "marriage" exclusively for opposite-sex couples posed at least a serious risk of denying the family relationship of same-sex couples such equal dignity and respect.

In Canada, the Supreme Court analogously suggested that dignity - as social acceptance and equal worth of all individualsimplied the unconstitutionality of reserving a second-class citizen status to gays and lesbians. As the Supreme Court wrote in Egan v Canada, "equality means that ... society cannot tolerate legislative distinctions that treat certain people as second-class citizens, that demean them, that treat them as less capable for no good reason, or that otherwise offend fundamental human dignity". ${ }^{10}$

The Constitutional Court of South Africa moved from a similar assumption when arguing in its same-sex marriage case, Fourie, that "the sting of past and continuing discrimination against both gays and lesbians was the clear message that it conveyed, namely, that they,

8 In Re Marriage cases, 43 Cal 4th 757 (2008), 770-80

9 In Re Marriage cases, cit., $43 \mathrm{Cal}$ 4th, 783.

10 Egan v Canada, [1995] 2 SCR513 § 104-05. 
whether viewed as individuals or in their same-sex relationships, did not have the inherent dignity and were not worthy of the human respect possessed by and accorded to heterosexuals and their relationships. This discrimination occurred at a deeply intimate level of human existence and relationality. It denied to gays and lesbians ... the concepts of equality and dignity, which at that point were closely intertwined, namely that all persons have the same inherent worth and dignity as human beings, whatever their other differences may be". ${ }^{11}$

Starting from these remarks, the Constitutional Court concluded that

the exclusion of same-sex couples from the benefits and responsibilities of marriage ... is not a small and tangential inconvenience resulting from a few surviving relics of societal prejudice destined to evaporate like the morning dew. It represents a harsh if oblique statement by the law that samesex couples are outsiders, and that their need for affirmation and protection of their intimate relations as human beings is somehow less than that of hetero- sexual couples. It reinforces the wounding notion that they are to be treated as biological oddities, as failed or lapsed human beings who do not fit into normal society, and, as such, do not qualify for the full moral concern and respect that our Constitution seeks to secure for everyone. It signifies that their capacity for love, commitment and accepting responsibility is by definition less worthy of regard than that of heterosexual couples. ${ }^{12}$

Finally, in same-sex marriage cases dignity comes into consideration as autonomy and self-determination of human beings concerning the most intimate and personal life choices. According to this interpretation, dignity is not an innate gift but the result of a process of development of human identity and personality.

In the United States the Supreme Judicial Court of Massachusetts argued in Goodridge v Department of Public Health, that "the core concept of common human dignity protected by U.S. Const. amend. XIV precludes government intrusion into the deeply personal realms 
of consensual adult expressions of intimacy and one's choice of an intimate partner. The central role that decisions whether to marry or have children bear in shaping one's identity has been reaffirmed". ${ }^{13}$ State supreme courts analogously developed the relationship between dignity and liberty in same-sex marriage cases arguing that marriage involved "the most intimate and personal choices a person may make in lifetime, choices central to personal dignity and autonomy". ${ }^{14}$

More recently, in its 2015 landmark case on same-sex marriage (Obergefell v. Hodges ${ }^{15}$ ), the Supreme Court of the Unites States referred to dignity of same-sex couples: although it also endorsed other interpretations of the principle of dignity, it put that principle in relation with autonomy and liberty, stating that "the fundamental liberties protected by [the Due Process Clause of the Fourteenth Amendment] include most of the rights enumerated in the Bill of Rights. ... In addition, these liberties extend to certain personal choices central to individual dignity and autonomy, including intimate choices that define personal identity and beliefs". ${ }^{16}$

In Europe, constitutional courts have analogously expounded the relationship between dignity and personal self-determination in their judgments on same-sex marriage. The Constitutional Tribunal of Spain, for instance, when concluding that equal marriage does not affect the institutional guarantee of marriage under Article 32 of the Constitution, emphasised that the recognition of the right to marry for same- sex couples also implied "respect for their own sexual orientation" and defined this achievement as "a step forward towards the guarantee of personal dignity and the free development of one's

13 Goodridge v Department of Public Health, cit.

14 See Bostic v Rainey, 970 F Supp 2d 456, 22 (ED Va 2014) but see also Kitchen v Herbert, 961 F Supp.

2d 1181 (D Utah 2013) 21 (Individual choices pertaining to marriage were found to be protected because they are 'integral to a person's dignity and autonomy').

15 Obergefell $v$. Hodges, $135 \mathrm{~S} \mathrm{Ct} 2584$ (2015).

16 Obergefell v. Hodges, $135 \mathrm{~S} \mathrm{Ct}, 2597$. 
personality under article 10(1) of the Spanish Constitution of 1978 that lie at the foundation of the Spanish constitutional order" ${ }^{17}$.

In Italy, where law no 76 of 2016 has introduced same-sex civil unions, while marriage is still precluded to same-sex couples, the Constitutional Court held that gays and lesbians enjoy a constitutional and fundamental right "to live freely their life as a couple" under Article 2 (which recognises and guarantees the fundamental rights of individuals and social groups) and under Article 3 of the Constitution (which enshrines the principle of equality and social dignity of all citizens) $)^{18}$

Finally, since its first case on same-sex marriage, the Constitutional Tribunal of Portugal has developed the idea that marriage should be granted to all individuals in a state bound by the rule of law and whose bill of rights is based on the primacy of freedom and human dignity. ${ }^{19}$

\section{The reasons behind the growing importance of dignity in human rights law adjudication}

Although none of the constitutional courts cited in the previous pages relied exclusively on dignity in order to conclude that marriage equality is mandated by (or complies with) the domestic constitutions, it is undeniable that same-sex marriage cases mirror the widespread diffusion of dignity discourse that dominates the present human rights adjudication.

Recent scholarship has analysed this development in a wider perspective, taking into account the different meanings of dignity and its relationship with equality and liberty in a wide variety of contexts. Identification of the various reasons behind the great expansion of dignity discourse in present human rights adjudication falls outside the

17 Case n. 198/2012, § 11.

18 Case n. 138 of 15 April 2010, $\S 8$.

19 Acórdão n. 359/2009 (9 July 2009). 
subject area of this paper, but the conclusions reached by recent scholarly works may cast some light both on the usage and the circulation of dignity discourse even in same-sex marriage cases.

McCrudden has identified in particular several reasons to explain the increasing popularity of the concept of dignity among judges and advocates: he argues in the first place that when courts have to decide how to resolve conflicts of rights (or conflicts between rights and values), dignity provides "a language in which courts can indicate the weighting given to particular rights and other values in this context" (McCrudden, 2008, 716). This implies that once dignity enters the balancing, it determines the outcome of the case.

As I have argued in a previous work on this subject, this role of dignity as the "ultimate scale or principle against which to compare conflicting values" (McCrudden, 2008, 714) is apparent in same-sex marriage cases as well as in legal debates on same-sex marriage. As in the past both "pro-life" and "pro-choice" movements invoked dignity respectively in relation to the inherent value of human life and to the right of self-determination of women, today dignity is invoked both in support and against same-sex marriage (Siegel, 374). Whereas same-sex marriage proponents emphasise the inherent value of all human beings, their need for social recognition and their right to self-determination with respect to fundamental life choices in order to support equal marriage, conversely traditionalists and religious authorities frequently emphasise the "dignity of marriage" in order to promote an opposite vision of the nature, the origin, the ends and importance of marriage (Tollefsen, 2013, 482). In their perspective, sex complementarity is required to preserve the dignity of marriage and to defend traditional sexual roles. By contrast, same-sex marriage proponents object that the validity and dignity of opposite-sex marriage is not diminished by equal marriage because extending marriage to same-sex couples reinforces the importance of marriage to individuals and communities. 
In same-sex marriage cases, once the inherent value of all human beings regardless of their sexual orientation is assumed, dignity arguments tilt the balance in favour of equal marriage. Dignity triggers constitutional protection and it is interesting to note that even the Italian Constitutional Court - which in 2010 adopted an originalist interpretation of marriage and concluded that equal marriage is not mandated by the Constitution-as mentioned above analogously appealed to dignity and used this argument to support the recognition of the constitutional and fundamental right of gays and lesbians "to live freely their life as a couple". ${ }^{20}$

Nonetheless, in my opinion, dignity discourse is neither a rhetorical tool, nor a "a broad abstraction" (Rosen 2015): when the Supreme Court emphasised in United States v. Windsor that "until recent years, many citizens had not even considered the possibility that two persons of the same sex might aspire to occupy the same status and dignity as that of a man and woman in lawful marriage" 21 , or when the Spanish Constitutional Tribunal in 2012 argued that by introducing same-sex marriage in 2005 the legislator has made "a step forward ... towards guaranteed personal dignity and the free development of one's personality" 22 they were acknowledging "a process of transition [of gays and lesbians] from exclusion to inclusion" (Finck, 29).

At the same time, as I have already attempted to demonstrate in a previous work (Sperti, 2017, $102 \mathrm{ff}$.), courts' statements play a role which is detachable from the immediate purpose they serve: they help forging constitutional arguments and reinforcing constitutional values of liberty, equality and dignity enshrined in constitutional texts. Dignity, with its flexible meaning, not only "translates socio-cultural change in legal change" (Finck, 45): in my opinion it also strengthens that change, paving the way to further recognition of rights for gays and lesbians.

20 Case no 138 of 15 April 2010, para 8.

21 United States $v$ Windsor, 133 S Ct 2675, 2689.

22 Case no 198/2012, para 9. 
For this reason, remarks concerning the aspiration of samesex couples to no longer be deprived of the opportunity to enjoy their fundamental rights and the rights stemming from marriage have at the same time a normative value. As Glensy (2011, 135-6) emphasises, "all the representations of the right to dignity ... do not merely resolve a case, or set forth a legislative, constitutional, or international imperative, but instead provide something more - a statement of collective aspirations to be sought by all participating members of society".

McCrudden $(2008,714)$ has also suggested another reason for the widespread circulation of dignity discourse, in connection with "the need to decide how far the rights which are to be interpreted should be seen as instantiating international standards, as opposed to how far they should be seen as protecting more national or local concerns where there is a conflict". He suggests that dignity "gives us a conceptual tool to mediate the polarity of pluralism and the common good in a globalized world". In his opinion, dignity's role, "in practice, is to enable local context to be incorporated under the appearance of using a universal principle. Dignity, in the judicial context, not only permits the incorporation of local contingencies in the interpretation of human rights norms; it requires it. Dignity allows each jurisdiction to develop its own practice of human rights" (McCrudden, 2008, 714).

Addressing dignity discourse in transnational process with specific regard to debates over the regulation of sexuality, Siegel has instead suggested that claims of dignity are popular as well as professional and that they are also asserted outside courts, due in particular to the role played by social movements and religious organisations (Siegel, 2012, 167).

In my opinion (Sperti, 2017, 167) both the approaches capture some of the different aspects of dignity discourse in same-sex marriages cases at constitutional and supreme court level. Claims of dignity are shaped through debates at political and social movement level and advanced before lower courts before being expounded at constitutional 
and supreme court level. But at the same time, especially newly established constitutional courts (such as, for instance, the South Africa Constitutional Court or East European constitutional courts) resort to dignity discourse in order to emphasise the rupture of their domestic legal systems with previous constitutional orders. Hungary's Constitutional Court, for instance, since its first case (no 8 of 1990), developed a new concept of rights and used the argument of human dignity in order to set aside the provisions inherited from its past legal order and to reinterpret them in a liberal way. (Duprè, 2003) The Constitutional Court of South Africa has similarly emphasised the country's need 'to locate [itself] in the mainstream of international democratic practice'. ${ }^{23}$

But dignity discourse also provides a conceptual tool to mediate among different instances coming from new (ornewly recognised) groups and between the opposite aspirations to particularity and pluralism in present human rights adjudication. The idea of human dignity, as based on the inherent value of all human beings, satisfies an aspiration to the universal, but at the same time, when balanced with other constitutional rights or interpreted in the light of the general principles that inspire national constitutions, makes it possible to accommodate the social, moral, political specificities of each legal system (Sperti, 2017, 167).

\section{Dignity and "pluralism anxiety"}

In the United States-where in recent times the Supreme Court has frequently emphasised the connection between liberty, equality and human dignity-Yoshino has explained the development of those legal arguments on the basis of the 'pluralism anxiety', as the United States, he writes, "confront «new» kinds of people (introduced to the country through immigration) or newly visible people (introduced to the country by social movements)" (Yoshino, 2011, 747) Yoshino argues that the

23 Coetzee $v$ Government of the Republic of South Africa, Matiso v Commanding Officer Port Elizabeth Prison (CCT19/94, CCT22/94) [1995] ZACC 7 (22 September 1995), para 51. 
"apprehension of and about demographic diversity" is transforming the Supreme Court's traditional civil rights jurisprudence and forging the traditional model of equal protection, pressing the Court away from traditional group-based identity politics.

In his opinion, one of the main effects of this transformation lies in the limitation of the number of formally protected classifications, because "pluralism anxiety has operated, and will continue to operate, as a serious obstacle to the recognition of classification-specific judicial protections" by the Supreme Court. At the same time, Yoshino argues that pluralism anxiety is transforming constitutional civil rights jurisprudence, because "the Supreme Court has used liberty-based dignity analysis to mitigate its curtailment of group-based equality analysis. At the same time, 'the liberty-based dignity claim has been the Court's way of splitting the difference between a direct extension of equality analysis and its absolute foreclosure". (Yoshino, 2011, 776).

Other American scholars share the idea that the Supreme Court's decision not to rely in LGBT cases $^{24}$ on standard equal protection arguments or on the due process three-prong test in favour of a new foundational principle should be considered "a major shift in constitutional doctrine, one that will have ramifications in many cases to come" (Joshino, Yoshino, 2016, 179).

Tribe, for instance, writes that 'the important doctrinal work done by Justice Kennedy's in the same-sex marriage case (Obergefell v. Hodges ${ }^{25}$ ) represents the culmination of a decades-long project that has revolutionized the Court's fundamental rights jurisprudence (Tribe, 2015). In particular, he argues that Justice Kennedy's chief jurisprudential achievement "is to have tightly wound the double helix of Due Process and Equal Protection into a doctrine of equal dignityand to have located that doctrine in a tradition of constitutional

24 Lawrence v. Texas, 539 US 558 (2003); United States $v$ Windsor, cit.; Obergefell v. Hodges, 135 S Ct 2584 (2015).

25 Obergefell $v$ Hodges, cit., above fn 24. 
interpretation as an exercise in public education. ... Equal dignity, a concept with a robust doctrinal pedigree, does not simply look back to purposeful past subordination, but rather lays the groundwork for an ongoing constitutional dialogue about fundamental rights and the meaning of equality" (Tribe, 2015).

In my opinion, it is possible to identify an analogous relationship between the increasing reliance on liberty-based and equality-based dignity arguments and pluralism anxiety even in the judgments of other constitutional and supreme courts. Excluding more recent constitutions that explicitly prohibit different treatments based on sexual orientation ${ }^{26}$, with few exceptions ${ }^{27}$ constitutional and supreme courts have been refraining from defining sexual orientation as an unconstitutional ground of discrimination or from qualifying gays and lesbians as a discriminated minority.

For instance, instead of applying traditional formal equality patterns of adjudication and considering whether denial of marriage amounts to an unconstitutional discrimination under Article 14 of the Spanish Constitution, the Spanish Constitutional Tribunal stresses the

26 See eg the Constitution of Mexico of 1917 (as amended in 2015), Art 1; New Zealand Human Rights Act 1993, Arts 27(2), 45 and 59; Constitution of Portugal of 1976 (as amended in 2005), Art 13(2); Constitution of South Africa of 1996, Art 9(3); Constitution of Sweden of 1974, as amended in 2012, Art 1(2). See also Northern Ireland Act 1998, art 75(1); Scotland Act 1998, Sch 5, Pt II, subheading 2, head L, L2 (interpretation). See also on the interpretation of Art 14 of the European Convention on Human Rights and the principle that any difference in treatment based on sexual orientation requires 'very weighty' and 'particularly serious reasons' to justify it, Karner v Austria ECHR 2003-IX, § 37. The European Court of Human Rights has also clarified that a difference in treatment based solely on grounds of sexual orientation amounts to a discrimination under the ECHR in Kozak v Poland [2010] ECHR $280 § 91$ and Salgueiro da Silva Mouta v Portugal ECHR 1999-IX. The violation of equality under Art 3(1) of the German Constitution (Grundgesetz) has been also emphasised by the First Senate of the German Constitutional Tribunal in the order of 7 July 2009 (1 BvR 1164/07) on the pension scheme for civil service employees, arguing that 'the mere reference [in the law] to the requirement of protecting marriage did not justify a differentiation' between marriage and civil partnerships.

27 Haig v Canada (1992), 16 CHRR D/226 (Ont CA), Egan v Canada (1995) 2 SCR 513. 
violation of Article 10(1) concerning the guarantee of personal dignity and the free development of human personality, although in its earlier judgments it had qualified "sexual orientation" as an unconstitutional ground of discrimination. ${ }^{28}$

The principle of formal equality was dismissed as not relevant by the Italian Constitutional Court in case no 138 of 2010, mentioning instead, inter alia, human dignity and the right of same-sex couples "to live freely their life as a couple".

The French Conseil constitutionnel in its 2013 reference case on same-sex marriage simply emphasised that "the difference between couples comprised of a man and a woman and same-sex couples no longer justified the fact that the latter could no longer obtain the status and legal protection associated with marriage". ${ }^{29}$

This trend makes it possible to argue that the widespread use of dignity discourse instead of formal equality arguments is also due to the fact that dignity, with its flexible meaning, makes it possible for constitutional courts to accommodate different conception of human rights and to answer new claims of recognition without adopting more rigid standards of adjudication as those resulting from pure formal equality arguments.

At the same time, it is worth noting that constitutional and supreme courts, compared to lower courts, are concerned not only with pluralism anxiety but also with the future implications of their judgments: in this respect, arguments of dignity provide a convenient language to recognise gay and lesbian rights and at the same time make it possible to accommodate equality arguments on more contingent grounds.

\section{References}

28 See Case no 198/2012, cit.

29 Décision n. 2013-669, 17 May 2013 in part. Considérant n. 22. 
Barak, Aharon. 2015. Human Dignity. The Constitutional Value and the Constitutional Right. Cambridge: Cambridge University Press

Daly, Erin. 2013. Courts, Constitutions and the Worth of the Human Person. Philadelphia: University of Pennsylvania Press

Diduck, Alison, and Canagas, Felicity. Family Law, Gender and the State. Text, Cases and Materials, 3rd edn. Oxford: Hart Publishing

Dupré, Catherine. 2015. The Age of Dignity. Human Rights and Constitutionalism in Europe. Oxford: Hart Publishing

Finck, Michèle. 2016. "The Role of Human Dignity in Gay Rights Adjudication and Legislation: A Comparative Perspective." International Journal of Constitutional Law (ICon) 14, 3: 26-53

Glensy, Rex D. 2011. "The Right to Dignity." Columbia Human Rights Law Review 43,1: 65-142

McCrudden, Christopher. 2008. "Human Dignity and Judicial Interpretation of Human Rights." European Journal of International Law 19:4, 655-724

McCrudden, Christopher. 2014. "In Pursuit of Human Dignity. An Introduction to Current Debates." In Understanding Human Dignity, edited by Christopher McCrudden, 1-58. Oxford: Oxford University Press

Nussbaum. Martha. 2010. From Disgust to Humanity. Sexual Orientation and Constitutional Law. Oxford:, Oxford University Press

O’Mahoney, Conor. 2012. "There Is No Such Thing as a Right to Dignity" 10 International Journal of Constitutional Law (Icon), 10:2, $551-574$

Feldman, David. 1999. "Human Dignity as a Legal Value. Part I" Public Law, 16:682-702

Hofmann, Hasso. 1993. "Die versprochene Menschenwürde.” Archiv des öffentlichen Rechts 118,3: 353-377

Rao, Naomi. 2008. "On the Use and Abuse of Dignity in Constitutional Law." Columbia Journal of European Law 14, 2:201255 
Rao, Naomi. 2011. "Three Concepts of Dignity in Constitutional Law." Notre Dame Law Review 86:1 , 183-271

Rosen, Jeffrey, 2015 "The Dangers of a Constitutional Right to Dignity." The Atlantic, 29 April 2015

Siegel, Reva. 2012. "Dignity and Sexuality: Claims of Dignity in Transnational Debates over Abortion and Same-Sex Marriages." International Journal of Constitutional Law 10:2, 355-379

Sperti, Angioletta. 2017. Constitutional Courts, Gay Rights and Sexual Orientation Equality, Oxford: Hart Publishing

Tollefsen, Christopher. 2013. "The Dignity of Marriage." In Understanding Human Dignity, Christopher McCrudden editor, 482499. Oxford: Oxford University Press

Tribe, Lawrence H. 2015. "Equal Dignity: Speaking Its Name." Harvard Law Review Forum, 1:16, 129

Zanetti, Gianfrancesco. 2015. L'orientamento sessuale. Cinque domande tra diritto e filosofia. Bologna: Il Mulino

Vincenti, Umberto. 2009. Diritti e dignità umana. Roma-Bari: Laterza

Yoshino, Kenji. 2011. "The New Equal Protection." Harvard Law Review 124, : 747-803

Yoshino, Kenji, 2016. "A New Birth of Freedom? Obergefell v Hodges" Harvard Law Review 129: 147-170. 